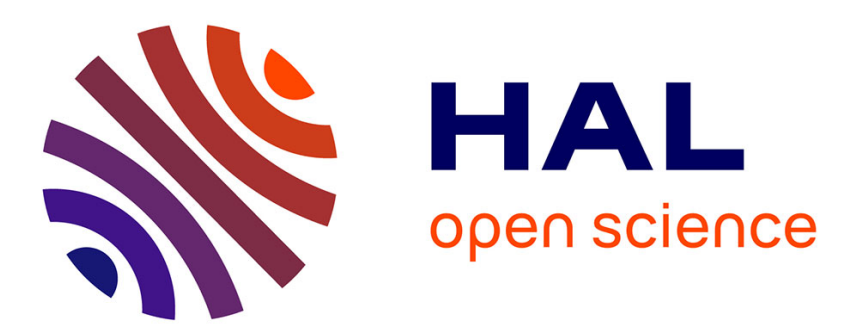

\title{
Influence of protein standardization and UHT heating on the furosine value and freezing point of milk
}

W Rattray, P Gallmann, P Jelen

\section{To cite this version:}

W Rattray, P Gallmann, P Jelen. Influence of protein standardization and UHT heating on the furosine value and freezing point of milk. Le Lait, 1997, 77 (2), pp.297-305. hal-00929528

\section{HAL Id: hal-00929528 \\ https://hal.science/hal-00929528}

Submitted on 1 Jan 1997

HAL is a multi-disciplinary open access archive for the deposit and dissemination of scientific research documents, whether they are published or not. The documents may come from teaching and research institutions in France or abroad, or from public or private research centers.
L'archive ouverte pluridisciplinaire HAL, est destinée au dépôt et à la diffusion de documents scientifiques de niveau recherche, publiés ou non, émanant des établissements d'enseignement et de recherche français ou étrangers, des laboratoires publics ou privés. 
(C) Elsevier/INRA

\title{
Original article
}

\section{Influence of protein standardization and UHT heating on the furosine value and freezing point of milk}

\author{
W Rattray ${ }^{1}$, P Gallmann ${ }^{2}$, P Jelen ${ }^{1 *}$ \\ ' Department of Agricultural, Food and Nutritional Science, \\ University of Alberta, Edmonton, Alberta, Canada; \\ ${ }^{2}$ Federal Dairy Research Institute, Liebefeld, Switzerland
}

(Received 3 May 1996; accepted 30 September 1996)

\begin{abstract}
Summary - Milk containing $\sim 1.7 \%$ fat, but protein in the range $\sim 2.6-3.4 \%$ was prepared by mixing calculated quantities of whole milk, skim milk and an ultrafiltration (UF) permeate obtained from skim milk or quarg acid whey. The freezing point (FP) of each milk was measured before and after ultra-high temperature (UHT) heating. The concentration of lactuloselysine, determined indirectly as furosine value (FV), was measured after 1,4 or 12 weeks storage of the UHT milk at 4 or $25^{\circ} \mathrm{C}$. After UHT heat treatment, the FV was $\sim 2-4$-fold higher in indirect UHT milk $(\sim 18-47 \mathrm{mg} / \mathrm{L})$, compared to direct UHT milk ( 9-12 $\mathrm{mg} / \mathrm{L})$. Upon storage at $4{ }^{\circ} \mathrm{C}$, the $\mathrm{FV}$ did not change appreciably, but after 12 weeks at $25^{\circ} \mathrm{C}$, it increased by $\sim 1.5-4$-fold; some direct UHT milk products stored at $25^{\circ} \mathrm{C}$ had a greater FV than indirect UHT milk stored at $4{ }^{\circ} \mathrm{C}$. Standardization with skim milk permeate or acid whey permeate caused the FV of UHT milk to decline, but the effect was small compared to the influence of storage conditions. The use of increasing amounts of skim milk permeate for protein standardization caused the FP to increase progressively, while the opposite occurred upon standardization with acid whey permeate. Direct or indirect UHT heating had no effect on the FP of any milk, indicating that irreversible changes in milk salt equilibria did not occur and that thermal interactions of lactose, including its participation in the Maillard reaction, did not affect the FP.
\end{abstract}

protein standardization / UHT milk / furosine / freezing point

Résumé - Influence de la standardisation en protéine et du traitement UHT sur la teneur en furosine et le point de congélation du lait. Des échantillons de lait contenant environ 1,7\% de matière grasse et de teneur en protéine entre 2,6 et 3,4\% ont été préparés par mélange de quantités prédéterminées de lait entier, lait écrémé et de perméat provenant du traitement par ultrafiltration (UF) de lait écrémé ou de lactosérum acide obtenu lors de la production de quarg. Le point de congélation pour chaque échantillon de lait a été mesuré avant et après traitement UHT. La quantité de lactuloselysine déterminée par méthode indirecte et représentée par la teneur en furosine a été mesurée après des durées de stockage de 1,4 et 12 semaines du lait UHT à des températures de 4 et $25^{\circ} \mathrm{C}$. La

\footnotetext{
* Correspondence and reprints
} 
teneur en furosine s'est montrée 2 à 4 fois plus élevée pour le lait traité en UHT méthode directe $(18-47 \mathrm{mg} / \mathrm{L})$ comparé au lait traité en UHT méthode indirecte $(5-12 \mathrm{mg} / \mathrm{L})$. La valeur en furosine n'a pas changé significativement lors du stockage à $4{ }^{\circ} \mathrm{C}$, alors que pour un stockage à $25^{\circ} \mathrm{C}$ durant 12 semaines une augmentation de 1,5 à 4 fois est apparue; certains échantillons de lait traités par la méthode UHT directe et stockés à $25^{\circ} \mathrm{C}$ avaient une valeur en furosine plus grande que celle des échantillons traités par la méthode UHT indirecte et stockés à $4^{\circ} \mathrm{C}$. La standardisation avec perméat de lait écrémé et perméat de lactosérurm acide a produit une légère baisse de furosine pour le lait traité en UHT, mais les conditions de stockage on montré un effet supérieur sur la teneur en furosine. L'utilisation de quantités croissantes de perméat de lait écrémé pour la standardisation en protéine a produit une croissance progressive du point de congélation, alors que la standardisation avec perméat de lactosérum acide a produit un effet inverse. Le traitement UHT par méthode directe ou indirecte n'a eu aucun effet sur le point de congélation des échantillons de lait, montrant qu'aucun changement irréversible dans l'équilibre salin du lait n'est apparu et que les réactions dues au traitement thermique du lactose, réaction de Maillard incluse, n'ont pas affecté le point de congélation.

\section{standardisation en protéine / lait UHT / furosine / point de congélation}

\section{INTRODUCTION}

A number of methods exist to assess the severity of heat treatments applied to milk and other dairy products (Pellegrino et al, 1995). These include the measurement of inactivation of indigenous milk enzymes, whey protein denaturation or loss of its solubility, or determination of the concentration of heat-formed compounds in milk, such as lactulose or products of the Maillard reaction (MR). The manufacture of ultra-high temperature (UHT) milk involves relatively severe heat treatments, causing lactose to undergo a complex network of reactions, including its isomerization, degradation, and reaction with $\varepsilon$-amino groups of proteins in the initial stages of the MR (Berg, 1993).

Lactuloselysine (galactosefructoselysine) is an Amadori compound, generated by the reaction of a reducing sugar (lactose) with a free $\varepsilon$-amino group of lysine, and is found in milk during the early stages of the MR. The concentration of lactuloselysine in milk may be determined indirectly after its acid hydrolysis into pyridosine and furosine and by measuring the furosine value (FV) via high pressure liquid chromatography (HPLC). The recent development of rapid HPLC methods to measure furosine (Resmini et al, 1990; Henle et al, 1991;
Resmini and Pellegrino, 1991) have stimulated interest in the use of FV as a heat load indicator.

The principal factors affecting the formation of lactuloselysine in milk are the concentration of reactants (lactose and lysine) and fat, the heat load applied and the temperature at which the heat-treated milk is stored (Pellegrino, 1994). This multiplicity of factors complicates the correlation of FV with heat load; the FV can vary widely for milk products belonging to the same heat class (Pellegrino et al, 1995). It has been recommended that FV be reported as $\mathrm{mg}$ furosine per $\mathrm{mg}$ protein to allow a more direct correlation of FV to heat load, but this approach ignores the effect of possible variations in the fat and lactose content of milk and the effect of storage conditions.

The freezing point (FP) of unheated milk exhibits very little natural variation, but the influence of heat processing on the FP is less well known; if heating caused the concentration of low molecular weight entities to change, then the FP should change. Heating of milk initiates a complex network of reactions, including reactions of lactose (Berg, 1993) and changes in the partitioning of salts between the soluble and colloidal states (Holt, 1995), but the influence of these 
changes on the FP of milk has apparently not been experimentally determined.

Standardization of milk protein 'downward' by the addition of ultrafiltration (UF) permeate is a subject of considerable interest to the dairy industry. In a companion study (Rattray et al, 1996), the feasibility of producing protein-standardized UHT milk was investigated in terms of its nutritional and sensory quality and storage stability. For the same milk products, measurements indicating the effect of protein standardization and UHT heating on the FV and FP of milk were also carried out, the results of which are reported here. The particular objectives of the present study were: (1) to establish whether changes in the concentration of protein and lactose caused by protein standardization would interfere with the use of FV as an index of direct or indirect UHT heat treatment; and (2) to determine the effect of protein standardization and UHT heating on the FP of milk, especially to see if UHT heating would cause an irreversible change in milk salt equilibria, which could be detected by measurement of FP.

\section{MATERIALS AND METHODS}

\section{Preparation of protein-standardized UHT milk}

Normal and protein-standardized milk products were prepared by a procedure described previously (Rattray et al, 1996). All milk products contained $\sim 1.7 \%$ fat and $\sim 3.4$ (control milk), $3.2,2.9$ or $2.6 \%$ protein; the 'down'-standardization was accomplished by using permeates derived by UF of skim milk or quarg acid whey. The milk products were UHT-heated by direct $\left(150{ }^{\circ} \mathrm{C}\right.$ for $\left.2.7 \mathrm{~s}\right)$ or indirect $\left(138^{\circ} \mathrm{C}\right.$ for $\left.1 \mathrm{~s}\right)$ treatments, as described earlier (Rattray et al, 1996), and stored in darkness at 4 or $25^{\circ} \mathrm{C}$ for 12 weeks. Each milk was prepared and UHT-heated on three separate occasions from three separately acquired batches of raw material. Milk containing skim milk permeate is identified in this report as $\mathrm{S} 1, \mathrm{~S} 2$ or $\mathrm{S} 3$, in order of increasing level of added skim milk permeate or decreasing protein content; similarly, milk with acid whey permeate is called $\mathrm{A} 1, \mathrm{~A} 2$ or $\mathrm{A} 3$.

\section{Compositional analyses}

The UHT milk products were assayed, after 1 week of storage at $4{ }^{\circ} \mathrm{C}$, for protein (IDF, 1993), lactose (IDF, 1974) and ash (Anonymous, 1987). The titratable acidities of the UF permeates were determined according to a previously described procedure (Anonymous, 1993).

\section{Determination of furosine value}

The FV of the UHT milk products was determined by the method of Resmini et al (1990). This involved acid hydrolysis of lactuloselysine into pyridosine and furosine and quantification of the furosine by HPLC. For calibration of the HPLC, $3 \mathrm{mg}$ of furosine (acquired from Neosystem Laboratoire, Strasbourg, France) was dissolved in $100 \mathrm{~mL}$ of $0.3 \mathrm{~mol} / \mathrm{L} \mathrm{HCl}$, and $10 \mathrm{~mL}$ of that solution was then dissolved in $90 \mathrm{~mL}$ of $0.3 \mathrm{~mol} / \mathrm{L} \mathrm{HCl}$. The $\mathrm{FV}$ was expressed as $\mathrm{mg}$ furosine per L of milk. For each milk, FV was determined in duplicate on three separate occasions and mean and standard deviation values calculated using all data $(n=6)$.

\section{Measurement of freezing point}

The FP of unheated skim milk permeate or acid whey permeate and unheated or UHT-heated milk samples was measured in ${ }^{\circ} \mathrm{C}$ by the cryoscopic FP determination method (IDF, 1991), using a Fiske MS cryoscope (Fiske Associates, Uxbridge, MA, USA). Measurement of FP was carried out in duplicate, on three separate occasions, and mean values and standard deviations were calculated from all data $(n=6)$.

\section{RESULTS AND DISCUSSION}

\section{Furosine value}

The effect of protein 'down' standardization with skim milk permeate or acid whey 
permeate on the composition of milk has been determined previously (Rattray et al, 1996). Of main concern here is the fact that standardization with increasing amounts of skim milk permeate caused a progressive decline in protein concentration, while the use of acid whey permeate caused protein and also lactose concentration to decline (table I); lactose and protein are the reactants involved in the formation of lactuloselysine. The influence of protein standardization and storage temperature on the furosine content of UHT milk is shown in table II; the relative importance of these parameters is summarized in table III.

Table I. Mean $(n=6)$ composition of skim milk ultrafiltration permeate, acid whey ultrafiltration permeate or direct UHT milk measured after 1 week of storage at $4{ }^{\circ} \mathrm{C}$.

Composition moyenne $(\mathrm{n}=6)$ du perméat de lait écrémé, perméat de lactosérum acide ou des échantillons de lait traités par la méthode UHT directe après 1 semaine de stockage à $4^{\circ} \mathrm{C}$.

\begin{tabular}{llll}
\hline Product & Protein & $\begin{array}{c}\text { Lactose } \\
\%(w / w)\end{array}$ & Ash \\
\hline $\begin{array}{c}\text { Skim milk } \\
\text { permeate }\end{array}$ & $0.19(0.04)$ & $4.97(0.17)$ & $0.46(0.01)$ \\
$\begin{array}{c}\text { Acide whey } \\
\text { permeate }\end{array}$ & $0.22(0.06)$ & $4.32(0.06)$ & $0.73(0.01)$ \\
Control & $3.36(0.03)$ & $4.98(0.24)$ & $0.74(0.01)$ \\
S1 & $3.18(0.05)$ & $4.99(0.25)$ & $0.73(0.02)$ \\
S2 & $2.90(0.06)$ & $5.02(0.23)$ & $0.71(0.02)$ \\
S3 & $2.55(0.05)$ & $4.99(0.22)$ & $0.68(0.02)$ \\
A1 & $3.14(0.09)$ & $4.96(0.28)$ & $0.72(0.04)$ \\
A2 & $2.91(0.03)$ & $4.86(0.29)$ & $0.75(0.02)$ \\
A3 & $2.58(0.05)$ & $4.78(0.33)$ & $0.79(0.03)$ \\
\hline
\end{tabular}

S1, S2, S3 indicate milk with increasing amounts of skim milk permeate; A1, A2, A3 indicate milk with increasing amounts of acid whey permeate. Numbers in brackets show the standard deviations.

S1, S2, S3, lait avec une quantité croissante en perméat de lait écrémé ; $A 1, A 2, A 3$, lait avec une quantité croissante en perméat de lactosérum acide. Les chiffres entre parenthèse représentent la dêviation standard.
The FV was much higher in the indirect UHT milk in comparison to the direct UHT milk, when the products were 1 week old, which could have been due to two effects: (a) the higher total heat load applied during indirect UHT treatment (Nangpal et al, 1990a); (b) the effect of temporary dilution, caused by steam infusion during direct UHT treatment, on MR kinetics (Nangpal et al, 1990b). The non-instantaneous nature of heating and cooling and the more intense pre-heating of the milk in indirect UHT heating causes milk to experience a greater heat load compared to direct UHT heating. This more severe heating would increase the rate of formation of lactuloselysine; collision frequency between reactants would be increased and a greater number of molecules would have energies equal to the activation energy $\left(\Delta E^{*}\right)$.

In direct UHT heat treatment, the dilution of reactants coincides with the maximum temperature of heating, which has been conjectured to have a considerable effect on the rate of formation of lactulose and lactuloselysine. From experimental data, Nangpal et al (1990b) showed that for the same heat load, increasing the concentration of lactose in milk led to greater formation of lactulose and furosine, and argued, by calculation, that this was caused by a concomitant increase in the pre-exponential factor $\left(k_{0}\right)$ of the Arrhenius equation [ $k=k_{0}$ $\exp \left(-\Delta E^{*} / R T\right)$, where $k$ is the rate constant, $R$ the universal gas constant and $T$ is the absolute temperature]. This hypothesis should be treated with caution; to simplify their calculations, Nangpal et al (1990b) assumed that the formation of furosine approximately obeyed zero order kinetics, yet at the same time suggested that $k_{0}$ and hence the reaction rate was a function of concentration; these two postulates are mutually exclusive. In a systematic study, Berg (1993) discussed the complexity of the thermal reactions of lactose and stressed the importance of considering the complete matrix of reactions in order to calculate reli- 
Table II. Influence of protein standardization, UHT heat treament and storage on the mean $(n=6)$ furosine content of milk.

Influence de la standardisation en protéine, du traitement UHT et du stockage sur la teneur moyenne $(\mathrm{n}=6)$ en furosine des échantillons de lait.

\begin{tabular}{|c|c|c|c|c|c|c|c|c|}
\hline \multirow{2}{*}{$\begin{array}{l}\text { Heat } \\
\text { treatment }\end{array}$} & \multirow{2}{*}{$\begin{array}{c}\text { Storage } \\
\text { conditions } \\
\text { (weeks) }\end{array}$} & \multirow{2}{*}{ Control } & \multicolumn{5}{|c|}{ Furosine value $(\mathrm{mg} / \mathrm{L})$} & \multirow[b]{2}{*}{$A 3$} \\
\hline & & & SI & $S 2$ & S3 & $A l$ & $A 2$ & \\
\hline \multirow[t]{4}{*}{ Direct UHT } & $\left(4^{\circ} \mathrm{C}\right)$ & & & & & & & \\
\hline & 1 & $11.5(0.2)$ & $11.2(0.6)$ & $10.8(0.5)$ & $9.1(0.5)$ & $11.1(1.6)$ & $9.1(0.6)$ & $8.5(0.7)$ \\
\hline & 4 & $12.9(1.9)$ & $12.0(1.0)$ & $10.4(0.8)$ & $9.2(0.0)$ & $10.4(0.1)$ & $10.0(0.1)$ & $8.1(0.1)$ \\
\hline & 12 & $13.2(0.5)$ & $11.7(0.6)$ & $12.0(1.4)$ & $11.1(0.8)$ & $12.6(0.9)$ & $9.9(0.1)$ & $10.4(0.1)$ \\
\hline \multirow[t]{3}{*}{ Direct UHT } & $\left(25^{\circ} \mathrm{C}\right)$ & & & & & & & \\
\hline & 4 & $27.8(0.8)$ & $25.6(0.6)$ & $23.2(0.2)$ & $19.3(0.5)$ & $21.9(1.6)$ & $22.3(0.1)$ & $15.1(0.1)$ \\
\hline & 12 & $53.3(8.8)$ & $43.9(0.1)$ & $39.4(0.1)$ & $36.0(0.1)$ & $39.1(8.1)$ & $36.2(1.7)$ & $36.9(5.4)$ \\
\hline \multirow[t]{4}{*}{ Indirect UHT } & $\left(4^{\circ} \mathrm{C}\right)$ & & & & & & & \\
\hline & 1 & $46.8(5.8)$ & $32.0(1.7)$ & $29.7(2.4)$ & $26.9(5.1)$ & $35.1(1.7)$ & $28.1(1.1)$ & $17.5(1.1)$ \\
\hline & 4 & $43.4(1.4)$ & $40.2(3.5)$ & $33.3(0.8)$ & $25.7(1.6)$ & $37.0(1.8)$ & $35.4(0.1)$ & $20.7(0.1)$ \\
\hline & 12 & $42.0(3.7)$ & $36.3(5.8)$ & $29.7(0.5)$ & $25.7(0.9)$ & $30.6(6.6)$ & $27.7(0.6)$ & $17.0(1.7)$ \\
\hline \multirow[t]{3}{*}{ Indirect UHT } & $\left(25^{\circ} \mathrm{C}\right)$ & & & & & & & \\
\hline & 4 & $50.6(4.3)$ & $45.9(4.4)$ & $41.7(1.9)$ & $33.4(0.1)$ & $39.7(0.1)$ & $31.7(0.1)$ & $20.2(0.1)$ \\
\hline & 12 & $66.7(3.8)$ & $58.7(0.1)$ & $58.0(4.8)$ & $58.6(7.4)$ & $56.6(1.9)$ & $51.7(3.0)$ & $35.2(0.1)$ \\
\hline
\end{tabular}

$\mathrm{S} 1, \mathrm{~S} 2$ or S3 indicate milk with increasing amounts of skim milk ultrafiltration permeate; A1, A2 or A3 indicate milk with increasing amounts of acid whey ultrafiltration permeate. Numbers in brackets show the standard deviations.

S1, S2 ou S3, lait avec une quantité croissante en perméat de lait écrémé; A1, A2 ou A3, lait avec une quantité croissante en perméat de lactosérum acide. Les chiffres entre parenthèses représentent la déviation standard.

Table III. Relative importance of protein standardization, type of UHT heat treatment and storage temperature on the furosine value of milk.

Effet relatif de la standardisation en protéine, du traitement UHT et de la température de stockage sur la teneur en furosine des échantillons de lait.

\begin{tabular}{lcl}
\hline Factor & Effect $^{1}$ & Effect on furosine value related to: \\
\hline Protein standardization & & \\
With skim milk permeate & $\downarrow$ & Reduced [protein] \\
With acid whey permeate & $\downarrow \downarrow$ & Reduced [protein], [lactose] \\
UHT heating & $\uparrow \uparrow \uparrow$ & Heat load; temporary dilution of reactants \\
Direct & $\uparrow \uparrow \uparrow \uparrow$ & Heat load \\
Indirect & None & No Maillard reaction \\
Storage & $\uparrow \uparrow \uparrow$ & Slow Maillard reaction \\
$4^{\circ} \mathrm{C}$ &
\end{tabular}

\footnotetext{
${ }^{1}$ Effect was to increase the furosine value to a slight $(\uparrow)$, moderate $(\uparrow \uparrow)$, large $(\uparrow \uparrow \uparrow)$ or very large $(\uparrow \uparrow \uparrow \uparrow)$ extent, or to reduce the furosine value by a slight $(\downarrow)$, moderate $(\downarrow \downarrow)$, large $(\downarrow \downarrow \downarrow)$ or very large $(\downarrow \downarrow \downarrow \downarrow)$ extent. ${ }^{I}$ Accroissement en furosine léger $(\uparrow)$, modéré $(\uparrow \uparrow)$, élevé $(\uparrow \uparrow \uparrow)$ ou très élevé $(\uparrow \uparrow \uparrow \uparrow)$; ou diminution en furosine légère $(\downarrow)$, modérée $(\downarrow \downarrow)$, élevée $(\downarrow \downarrow \downarrow)$ ou très élevée $(\downarrow \downarrow \downarrow \downarrow)$.
} 
able kinetic parameters. The use of the Arrhenius equation to elucidate chemical kinetics can lead to oversimplification; the Eyring equation, based on minimization of free energy, has been recommended as a less empirical approach to understanding kinetics (van Boekel and Walstra, 1995).

The presence of increasing amounts of either UF permeate type caused the FV of UHT milk to decline and the effect was evident throughout storage, but it was too small to obscure the use of FV as an indicator of direct or indirect UHT heat treatment. For example, the seven direct UHT milk products stored for 1 week at $4{ }^{\circ} \mathrm{C}$ had FVs in the range $11.5-8.5 \mathrm{mg} / \mathrm{L}$; for indirect UHT milk the range was $46-17.5 \mathrm{mg} / \mathrm{L}$; since these values did not overlap, differences in protein and lactose concentration due to standardization did not lead to ambiguity in the use of the FV as a heat load indicator.

In general, the use of acid whey permeate for protein standardization led to a greater reduction in the FV compared to skim milk permeate. This may have been due to the fact that standardization of milk with acid whey permeate caused both protein (hence lysine) and lactose to be reduced, while the use of skim milk permeate only reduced protein. The decline of FV was greater in the indirect than in direct UHT milk. Conceivably, the more severe heating employed in the manufacture of indirect UHT milk accentuated the influence of the initial reactant concentration on the formation of lactuloselysine.

Storage of direct or indirect UHT milk at $25{ }^{\circ} \mathrm{C}$ caused a gradual increase in the $\mathrm{FV}$, while at $4{ }^{\circ} \mathrm{C}$ changes in the $\mathrm{FV}$ were negligible. After 12 weeks, the average increase of FV in all products was $\sim 18 \mathrm{mg} / \mathrm{L}$, which is of a similar magnitude to the FV increases of $\sim 15 \mathrm{mg} / \mathrm{L}$ after 6 weeks of storage of UHT milk at $30^{\circ} \mathrm{C}$ reported by Nangpal and Reuter (1990). The increase in $\mathrm{FV}$ at $25^{\circ} \mathrm{C}$ was probably caused by a slow MR, which would not occur at
$4{ }^{\circ} \mathrm{C}$. In some cases, the increase was so marked that if storage conditions were unknown it would not be possible to distinguish with confidence between direct and indirect UHT milk; when any direct UHT milk was stored at $25^{\circ} \mathrm{C}$ for 12 weeks, the FV was greater than that in indirect UHT milk stored at $4{ }^{\circ} \mathrm{C}$ for 1,4 or 12 weeks.

\section{Freezing point}

The principal milk constituents affecting its FP are lactose and dissolved salts, due to their relatively high molality in milk. Hydrophobic interactions between milk triglycerides cause them to spontaneously assemble into high molecular weight fat globules during milk biosynthesis, which have a very low molality in milk. Protein interacts with water in an extremely complex manner (Edsall and McKenzie, 1983), but due to its high molecular weight, is considered to have a very small effect on the FP of milk. However, in milk $\sim 2.0 \%$ of total water is involved in protein hydration, mainly due to hydration of casein micelles (Walstra and Jenness, 1984), which would reduce the amount of water available for dissolution of lactose and salts; the effect of this on FP apparently has not been studied. Milk contains $\sim 125 \mathrm{mmol}$ and $\sim 36 \mathrm{mmol}$ of soluble and colloidal salts per litre, respectively, (Holt, 1985), which corresponds to about one-third soluble and twothirds colloidal state on a mass basis. If the colloidal salts are considered to be a discrete part of the casein micelle, then they should not contribute to the FP depression of milk.

The mean FP of $1.7 \%$ fat milk, with $3.36 \%$ protein was $-0.525^{\circ} \mathrm{C}$, well within the range of normal milk. The FP values of skim milk permeate or acid whey permeate were -0.484 or $-0.654{ }^{\circ} \mathrm{C}$, respectively, and addition of these permeates to milk led to a progressively lower or higher FP (table IV), confirming the work of Rattray 
Table IV. Mean $(n=6)$ freezing point of skim milk ultrafiltration permeate, acid whey ultrafiltration permeate and protein-standardized UHT milk products, measured before heating or after 1 week at $4{ }^{\circ} \mathrm{C}$.

Valeur moyenne $(\mathrm{n}=6)$ du point de congélation du perméat de lait écrémé, perméat de lactosérum acide et des échantillons de lait standardisés en protéine avant traitement UHT ou après traitement UHT et I semaine de stockage à $4{ }^{\circ} \mathrm{C}$.

\begin{tabular}{|c|c|c|c|}
\hline \multicolumn{2}{|l|}{ Product } & \multicolumn{2}{|l|}{ Freezing point $\left({ }^{\circ} \mathrm{C}\right)$} \\
\hline \multirow{2}{*}{\multicolumn{2}{|c|}{$\begin{array}{l}\text { Skim milk permeate } \\
\text { Acid whey permeate }\end{array}$}} & $-0.484(0.006)$ & \\
\hline & & $-0.654(0.009)$ & \\
\hline & Before heating & After UHT (direct) & After UHT (indirect) \\
\hline Control & $-0.527(0.005)$ & $-0.527(0.002)$ & $-0.521(0.005)$ \\
\hline S1 & $-0.524(0.002)$ & $-0.524(0.002)$ & $-0.520(0.002)$ \\
\hline $\mathrm{S} 2$ & $-0.521(0.004)$ & $-0.523(0.001)$ & $-0.517(0.003)$ \\
\hline S3 & $-0.517(0.006)$ & $-0.517(0.006)$ & $-0.518(0.001)$ \\
\hline A1 & $-0.545(0.019)$ & $-0.535(0.001)$ & $-0.532(0.002)$ \\
\hline A2 & $-0.557(0.007)$ & $-0.553(0.003)$ & $-0.551(0.001)$ \\
\hline A3 & $-0.573(0.002)$ & $-0.573(0.001)$ & $-0.571(0.002)$ \\
\hline
\end{tabular}

S1, S2, S3 indicate milk with increasing amounts of skim milk permeate; A1, A2, A3 indicate milk with increasing amounts of acid whey permeate. Numbers in brackets show the standard deviations.

$S 1, S 2, S 3$ : lait avec une quantité croissante en perméat de lait écrémé ; A1, A2, A3, lait avec une quantité croissante en perméat de lactosérum acide. Les chiffres entre parenthèses représentent la déviation standard.

and Jelen (1996a). The high FP of the skim milk permeate was caused by its low ash content (table I), which in turn was probably related to conditions during UF which caused increased retention of minerals. The mineral content of the acid whey permeate was similar to that of normal milk, but because much of the salts in milk are associated with casein they would be expected not to contribute to the FP depression, whereas the salts in the acid whey permeate must have been completely soluble in the absence of protein and hence led to a greater depression of FP. Milk with acid whey permeate had a lower concentration of lactose than normal milk but a greater amount of organic acids, evidenced by the greater titratable acidity of the acid whey permeate $\left(65^{\circ} \mathrm{Th}\right)$, compared to normal milk ( $\left.16^{\circ} \mathrm{Th}\right)$; the greater content of organic acid probably compensated for the tendency of a reduced concentration of lactose to increase the FP.

When milk is heated, it undergoes a complex matrix of reactions including isomerization and degradation of lactose and its reaction with lysine (Berg, 1993), changes in salt equilibria (Holt, 1995), dephosphorylation of casein, and denaturation and aggregation of proteins (McCrae and Muir, 1995); the effects of these changes on the colligative properties of milk, including FP, has not received much attention. The FP of control or protein-standardized milk after direct or indirect UHT heating was virtually unchanged, indicating that the heating process did not change the overall molality of milk or, if it did, the change was reversible. During heating of milk, association of salts with casein micelles increases, but the shift is reported to be freely reversible upon cooling, the rate of re-equilibration decreasing 
with increasing severity of heat treatment (Geerts et al, 1983). When milk was heated at $85^{\circ} \mathrm{C}$ for $40 \mathrm{~min}$ and cooled to $4{ }^{\circ} \mathrm{C}$ for $24 \mathrm{~h}$, almost all of the calcium and phosphorus that had been heat-precipitated reverted to the native state (Pouliot et al, 1989). Thus, in the present study, the storage of direct UHT milk for 1 week at $4{ }^{\circ} \mathrm{C}$ would be expected to provide ample time for milk salts to return to their normal state, after a heat-induced shift in salt equilibria.

The furosine data indicate that the MR took place to a significant extent in the direct and especially indirect UHT milk products (table II), but this did not have a noticeable effect on FP. The MR and other reactions of lactose are complicated (Berg, 1993) and attempting to predict their influence on the colligative properties of milk would be difficult. However, any possible effect would be extremely small, considering that the concentration of lactose in the UHT milk products was $\sim 1000-5000$ times greater than the FV. Thus, the proportion of lactose involved in the MR and other thermal reactions was negligible and any accompanying changes in molality were too small to affect the FP of milk.

\section{CONCLUSIONS}

The FV of freshly-processed indirect UHT milk was consistently greater than that in direct UHT milk, despite fluctuations in the concentration of the reactants, lactose $(\sim 4.8-5.0 \%, w / w)$ and protein $(\sim 2.6-3.4 \%$, $\mathrm{w} / \mathrm{w})$, involved in the heat-induced formation of furosine. After 12 weeks at $25^{\circ} \mathrm{C}$, some direct UHT milk products had a greater FV than indirect UHT milk products stored at $4{ }^{\circ} \mathrm{C}$ for $1-12$ weeks. Thus, inadequate knowledge of storage conditions of UHT milk could have led to an incorrect correlation of FV with the severity of UHT heat treatment, while fluctuations in the concentration of protein and lactose caused by protein standardization were of lesser importance.

The FP of normal milk or any proteinstandardized milk was not altered significantly after direct or indirect UHT heat treatment, when the FP of UHT milk was measured after 1 week of storage at $4{ }^{\circ} \mathrm{C}$. This indicates that any changes in the partitioning of milk salts which may have occurred upon UHT direct or indirect heating were reversible. Although UHT heating and storage at $25^{\circ} \mathrm{C}$ caused the MR to proceed to a significant extent, this had no measurable effect on the FP of milk.

\section{ACKNOWLEDGMENTS}

The authors of this study are indebted to $R$ Badertscher and U Bütikofer who organized the compositional analyses, and to W Strahm who was involved in the preparation and heat treatment of the milk products. We thank P Eberhard for helping to safeguard the storage of the UHT milk. Discussions with J Meyer on the kinetics of lactuloselysine formation were most helpful. J Bourgois is thanked for providing the necessary French translations. W Rattray extends sincere thanks to EFAM for the invitation to engage in a collaborative study and for the hospitality experienced during a visit there.

\section{REFERENCES}

Anonymous (1987) Bestimmung der Asche. Gravimetrisch. Schweizerischeslebensmittelbuch $\sec 1.5 .3$

Anonymous (1993) Bestimmung der Titrierbaren Săure (Säurezahl). Schweizerischeslebensmittelbuch sec 1.5 .3

Berg HE (1993) Reactions of lactose during heat treatment of milk: a quantitative study. PhD thesis, Agric Univ Wageningen, The Netherlands

Edsall JT, McKenzie HA (1983) Water and proteins. II. The location and dynamics of water in protein systems and its relation to their stabilty and properties Adv Biophys 16, 53-183

Geerts JP, Bekhof JJ, Sheerjon JW (1983) Determination of calcium ion activities in milk with an ion selective electrode. A linear relationship between the logarithm of time and the recovery of the cal- 
cium ion activity after heating. Neth Milk Dairy $J$ 37, 197-211

Henle T, Walter H, Krause I, Klostermeyer H (1991) Efficient determination of individual milk compounds in heat-treated milk products by amino acid analysis. Int Dairy J 1, 125-135

Holt C (1985) The milk salts: their secretion, concentrations and physical chemistry. In: Developments in Dairy Chemistry. 3. Lactose and Minor Constituents (Fox PF, ed) Elsevier, London, 143-181

Holt C (1995) Effect of heating and cooling on the milk salts and their interaction with casein. In: Heatinduced Changes in Milk (Fox PF, ed) IDF spec issue 9501, International Dairy Federation, Brussels, Belgium, 105-133

IDF (1974) Determination of the lactose content of milk. Standard 28A. International Dairy Federation, Brussels, Belgium

IDF (1993) Milk. Determination of nitrogen content. Standard 20B. International Dairy Federation, Brussels, Belgium

IDF (1991) Milk. Determination of freezing point (Thermistor cryscope method). Standard I08B. International Dairy Federation, Brussels, Belgium.

McCrae CH, Muir DD (1995). Heat stability of milk. In: Heat-induced Changes in Milk (Fox PF, ed) IDF spec issue 9501, International Dairy Federation, Brussels, Belgium, 206-230

Nangpal A, Reuter H (1990) Reference diagram for furosine content in UHT milk. Kiel Milchwirtsch Forschungsber 42, 77-86

Nangpal A, Reuter H, Dehn-Müller B, Erbersdobler HF (1990a) Formation of furosine during UHT treatment of milk - comparison between direct and indirect heating. Kiel Milchwirtsch Forschungsber $42,43-51$

Nangpal A, Reuter H, Kiesner C (1990b) Reaction kinetics of lactulose and furosine formation - influence of dilution of milk during direct UHT treatment. Kiel Milchwirtsch Forschungsber 42, 53-64
Pellegrino L (1994) Influence of fat content on some heat-induced changes in milk and cream. Neth Milk Dairy $J 48,71-80$

Pellegrino L, Resimini P, Luf W (1995) Assessment (indices) of heat treatment of milk. In: Heat-induced Changes in Milk (Fox PF, ed) IDF spec issue 9501, International Dairy Federation, Brussels, Belgium, 409-453

Peter S, Rattray W, Jelen P (1996) Heat stability and sensory quality of fat-and protein-standardized milk. Milchwissenschaft 51, 611-616

Pouliot Y, Boulet M, Paquin M (1989) Observations on the heat-induced salt balance changes in milk. II. Reversibility on cooling. J Dairy Res 56, 193-199

Rattray W, Jelen P (1996a) Freezing point and sensory quality of skim milk as affected by addition of ultrafiltration permeates for protein standardization. Int Dairy J 6, 569-579

Rattray W, Jelen P (1996b) Protein standardization of milk and dairy products. Trends Food Sci Technol 7, 227-234

Rattray W, Gallmann P, Jelen P (1997) Nutritional, sensory and physico-chemical characterization of protein-standardized UHT milk. Lait 77, 279-296

Resmini P, Pellegrino L (1991) Analysis of food heat damage by direct HPLC of furosine. Int Chromatogr Lab 6, 7-11

Resmini P, Pellegrino L, Batelli G (1990) Accurate quantification of furosine in milk and dairy products by a direct HPLC method. Ital J Food Sci 2 , 173-183

van Boekel MAJS, Walstra P (1995) Use of kinetics in studying heat-induced changes in foods. In: Heatinduced Changes in Milk (Fox PF, ed) IDF spec issue 9501, International Dairy Federation, Brussels, Belgium, 22-50

Walstra P, Jenness R (1984) Dairy Chemistry and Physics. John Wiley and Sons, New York, 42-57 